\title{
P 35
}

\section{インターネット上に見る救急医療情報}

\section{○野口貴志 ${ }^{1,4}$ 高安英樹 2 高橋博樹 ${ }^{3}$ 南 浩一郎 ${ }^{4}$ 郡山一明 4 重松昭生 ${ }^{4}$}

1 ,産医研 2 ,東芝本社 3 ,東芝横浜事業所 4 ,産業医科大学麻酔科学教室

[はじめに]救急医療体制において一次救命処置が重要である。この事より企業においても救急蘇生法を習得した人がい ることが望ましい。一方、産業現場においても実際の事故が発生した際に医療機関へ搬送するまでの間の救急処置、搬送 されるまでの時間、連絡体制がその被災者の救命の鍵になる。一方ここ数年のコンピューターの普及ぶりは目覚ましく容 易にインターネットに接続し、様々な情報を瞬時に得ることが可能になった。今回我々はインターネット上に発信されて いる情報としての救急蘇生法、および救急処置法について調査した。

[方法]今回我々はインターネット上のサーチエンジンYahoo（ヤフー）,Japan (http://www.yahoo.co.jp) を用い「救急」、

「救命」、「蘇生」の3つのキーワードをもとに日本国内の web ページを検索した。さらに web ページの内容を閲覧した うえで救急蘇生法、救急処置法に関与していると考えられる web ページを選択した。更に東芝本社従業員においてイン ターネットの利用状況と救急蘇生法の普及状況、また今回のようなインターネット上の救急医療情報についてのアンケー 卜調查を実施した。

[結果、考察]（1）今回の検索において救急蘇生法、救急処置法についての内容を掲載している web ページは 32 件であ つた。（2）web ページの作者（責任者）は大学病院などの教育機関、消防団などの公的機関および医師、消防士、救 急救命士の個人の web ページに大別されるが中でも消防士および救急救命士の個人的 web ページが大部分を占め全体の 40\%を占めた。またアンケート調査により従業員のうち救急蘇生の経験がある、もしくはその内容を理解していると述 ベたものは 54\%にかぎられていた。また従業員の $77 \%$ 代インターネットを利用していたがインターネット上の救急医療 情報について知っていたものはわずか $14 \%$ に限られていたことが明らかになった。

[まとめ] インターネット上に救急蘇生法、救急処置法の情報が多く存在していた。産業現場における被災者の救命のた めに今回のような情報を救急教育に活用していくことは有効で㧍ると思われる。

\begin{tabular}{|c|c|}
\hline 作者(責任者) & アドレス \\
\hline 愛媛大学 & http://hypnos.m.ehime-u.ac.jp/GHDNet/japanese/connection.html \\
\hline 近畿大学 & http://www.med.kindai.ac.jp/kyumei/html/home.html \\
\hline 宮崎市郡医師会病院 & http://www.mnet.ne.jp/ hospital/ \\
\hline 宇治德州会病院救急部 & http://web.kyoto-inet.or.jp/people/sa0919/ \\
\hline 外科開業医 & http://www.marin.or.jp/yamato/default.htm \\
\hline 眼科医師 & http://www3.osk.3web.ne.jp/ adachim/ \\
\hline 眼科医師 & http://kondo-eye-info.com/ \\
\hline 耳鼻科師 & http://www.st.rim.or.jp/ kawaijib/kyukyu.html \\
\hline 日本赤十字社 & http://www.sphere.ad.jp/redcross/kyukyu/kyukyu.html \\
\hline 東京消防庁 & http://www.tfd.metro.tokyo.jp/iridex.html \\
\hline 消防団 (公式) & http://www.city.inuyama.aichi.jp/inuyama/fire/index.html \\
\hline 消防団 (公式) & http://www.g-web.com/JVFA/ \\
\hline 消防団 (公式) & http://www.cosmo.ne.jp/ taruga/index.html \\
\hline 救急救命士 & http://member.nifty.ne.jp/emt/ \\
\hline 救急救命士 & http://www3.justnet.ne.jp/ katsumi-kawahara/ \\
\hline 救急救命士 & http://apollo.m.ehime-u.ac.jp/ sitoh/ \\
\hline 救急救命士 & http://member.nifty.ne.jp/ems/ \\
\hline 救急救命士 & http://www.jomon.or.jp/ ${ }^{\sim}$ takeuchi/profile/profile.html \\
\hline 消防士 & http://www.sannet.ne.jp/userpage/no_nagai/ \\
\hline 消防士 & http://www.niseko.or.jp/niseko/kb/kta/welcome.htm \\
\hline 消防士 & http://www.tama.or.jp/ ben/ \\
\hline 消防士 & http://www.asahi-net.or.jp/ ${ }^{\sim} y w 2 h-i m n s / i n d e x . h t m$ \\
\hline 消防士 & http://www.sanmedia.or.jp/shiro/ \\
\hline 消防士 & http://www.ic-net.or.jp/home/hiroto/kyuukyuu.htm \\
\hline 消防士 & http://www.warp.or.jp/ muraoka/ \\
\hline 救急救命士·看護婦 & http://www3.justnet.ne.jp/〜 hikita/ \\
\hline 公認救急蘇生指導員 & http://www.cc.cuc.ac.jp/ ^scorp on/contents.html \\
\hline 患者 & http://www4.justnet.ne.jp/ sigeru-adr/ \\
\hline LSO & http://www.asahi-net.or.jp/〜rj6k-itu/ \\
\hline ライフセービング団体 & http://ha1.seikyou.ne.jp/home/tsubasa/savedarena/index.html \\
\hline 医学部学生 & http://www02.u-page.so-net.ne.jp/sb3/kobuhei/opening2.html \\
\hline ボランティア団体 & http://www.keis.co.jp/kyoto/srv/ \\
\hline
\end{tabular}

